\title{
Ribonucleic Acid Metabolism in the Liver after Administration of Individual Amino Acids
}

\author{
BY H. N. MUNRO AND D. MUKERJI \\ Department of Biochemistry, The University, Glasgow
}

(Received 9 December 1957)

The effects of protein deficiency on the metabolism of ribonucleic acid in the liver have already been described (Munro, Naismith \& Wikramanayake, 1953; Clark, Naismith \& Munro, 1957). The amount of ribonucleic acid in the liver falls rapidly during the first day of protein depletion and then becomes adjusted at a lower level. During the initial phase of reduction, uptake of ${ }^{32} \mathrm{P}$ and of $\left[{ }^{14} \mathrm{C}\right]$ glycine by ribonucleic acid is greatly diminished. This is probably due to breakdown products of ribonucleic acid causing dilution of labelling among the precursors used for its synthesis. Feeding of protein prevents this dilution effect, as is evidenced by the rapid restoration of labelling of ribonucleic acid. This suggests that the breakdown is partly or wholly suspended while dietary amino acids are being absorbed from the gut. These findings led us to conclude that the stability of liver ribonucleic acid is determined by the supply of amino acids for synthesis of protein. Consequently, it was of interest to know whether the metabolism of liver ribonucleic acid is affected by feeding with a protein deficient in one or more essential amino acids. This question has now been examined by using zein as the test protein. Contrary to expectation, zein was found to be almost as effective as casein in obliterating evidence of breakdown of ribonucleic acid. Extension of these studies to mixtures of amino acids confirmed that changes in metabolism of ribonucleic acid are not dependent on all essential amino acids being fed simultaneously. Individual amino acids were then administered singly, and it was found that glycine, methionine and leucine were each capable of producing a considerable effect on the metabolism of liver ribonucleic acid. The high leucine content of zein is sufficient to account for a large part of its action on the metabolism of ribonucleic acid.

\section{EXPERIMENTAL METHODS}

Animals and diets. Male albino rats weighing about 180$200 \mathrm{~g}$. were housed in separate cages under thermostatic conditions. They were fed on a synthetic diet (Munro \& Naismith, 1953) in two portions: the morning meal provided vitamins, minerals, $4 \cdot 3 \mathrm{~g}$. of carbohydrate and $0 \cdot 2 \mathrm{~g}$. of fat, and the evening meal contained $1.3 \mathrm{~g}$. of carbohydrate, $0.5 \mathrm{~g}$. of fat and all the dietary protein $(2 \cdot 2 \mathrm{~g}$. of casein). The rats quickly learned to consume these meals promptly. After about 3 or 4 days on the diet the test protein or amino acid was substituted for the casein of the evening meal; control animals received only the carbohydrate and fat of this meal. The few animals which did not eat the final meal promptly were rejected. The remainder received $40 \mu \mathrm{c}$ of ${ }^{32} \mathrm{P}$ by intramuscular injection $1 \mathrm{hr}$. later. They were killed the next day, $18 \mathrm{hr}$. after injection. Thus the period of labelling coincided with absorption of the final test meal.

Removal and analysis of liver. The rats were killed by exsanguination. After perfusion with $0.9 \% \mathrm{NaCl}$, the liver was excised and analysed for ribonucleic acid phosphorus (RNA P) and in some cases protein $\mathrm{N}$ by procedures described previously (Clark et al. 1957). These constituents are expressed as $\mathrm{mg} . / 100 \mathrm{~g}$. body wt., in order to indicate the total amount in the liver corrected for small variations in the initial size of the animals used.

The specific activities of the inorganic phosphate of the liver and of the individual ribonucleotides of ribonucleic acid (RNA) were measured by the procedures used earlier (Clark et al. 1957). In the tables, the specific activity of RNA $P$ is given as a percentage of the specific activity of the inorganic phosphate fraction of the same liver (relative specific activity). In order to estimate the total incorporation into RNA $P$ per liver, the total relative activity (Campbell, Olley \& Blewett, 1949) was computed. This was obtained by multiplying the total amount of RNA P in the liver (mg./100 g. body wt.) by the percentage figure obtained for relative specific activity.

Test protein and amino acids. Zein, the only nutritionally incomplete protein studied, was obtained commercially and gave a negative glyoxylic acid test. The casein used was unextracted grade (Glaxo Laboratories Ltd., Greenford, Middlesex).

The amino acid mixtures used in the experiments reported in Table 2 were compounded in the proportions found to be optimum for rat growth by Rose, Oesterling \& Womack (1948). Two mixtures were given, one consisting of all the essential amino acids except tryptophan, and the second containing only non-essential amino acids. Rats fed on the former mixture received $100 \mathrm{mg}$. of L-arginine hydrochloride, $40 \mathrm{mg}$. of L-cystine, $190 \mathrm{mg}$. of L-histidine hydrochloride, $240 \mathrm{mg}$. of DL-isoleucine, $240 \mathrm{mg}$. of $\mathrm{L}$ leucine, $300 \mathrm{mg}$. of L-lysine hydrochloride, $160 \mathrm{mg}$. of $\mathrm{L}$ methionine, $240 \mathrm{mg}$. of L-phenylalanine, $140 \mathrm{mg}$. of Lthreonine, $120 \mathrm{mg}$. of L-tyrosine and $200 \mathrm{mg}$. of L-valine per rat. The latter mixture provided $40 \mathrm{mg}$. of L-alanine, $800 \mathrm{mg}$. of L-aspartic acid, $1200 \mathrm{mg}$. of L-glutamic acid, $400 \mathrm{mg}$. of glycine, $40 \mathrm{mg}$. of L-proline and $400 \mathrm{mg}$. of $\mathrm{DL}-$ serine per rat. $\mathrm{NaHCO}_{3}$ was added where necessary to neutralize acidic amino acids. 
The significance of the high leucine content of zein was investigated by feeding with a mixture of amino acids in the proportions found in that protein (Block \& Bolling, 1951). Each rat received $216 \mathrm{mg}$. of $\mathrm{L}$-alanine, $34 \mathrm{mg}$. of $\mathrm{L}$ arginine hydrochloride, $105 \mathrm{mg}$. of L-aspartic acid, $19 \mathrm{mg}$. of L-cystine, $501 \mathrm{mg}$. of L-glutamic acid, $32 \mathrm{mg}$. of $\mathrm{L}$ histidine hydrochloride, $138 \mathrm{mg}$. of L-isoleucine, $439 \mathrm{mg}$. of L-leucine, $44 \mathrm{mg}$. of L-methionine, $121 \mathrm{mg}$. of L-phenylalanine, $196 \mathrm{mg}$. of L-proline, $57 \mathrm{mg}$. of L-threonine, $2 \mathrm{mg}$. of L-tryptophan, $98 \mathrm{mg}$. of L-tyrosine, $146 \mathrm{mg}$. of DL-serine and $57 \mathrm{mg}$. of L-valine. A control series of rats received an additional $298 \mathrm{mg}$. of L-alanine in place of the $439 \mathrm{mg}$. of leucine.

Individual amino acids were usually given in $1 \mathrm{~g}$. quantities, because this was generally the maximum amount which most animals would voluntarily consume in the evening meal. All were commercial preparations, the glycine (British Drug Houses Ltd.) being of AnalaR quality. The L-leucine (British Drug Houses Ltd.) was stated to contain traces of L-isoleucine; estimation of its sulphur content (Young, Edson \& McCarter, 1949) showed that it could not have been significantly contaminated by methionine. The action of L-leucine on metabolism of RNA is unlikely to be due to contaminants, since synthetic DLleucine has a similar effect (Table 4).

Dose-response curves with individual amino acids. For three amino acids, the response of metabolism of RNA to different doses was investigated on rats of closely similar weight. With glycine, the mean body weight at different dose levels varied from 202 to $209 \mathrm{~g}$., with methionine from 202 to $210 \mathrm{~g}$., and with leucine from 175 to $188 \mathrm{~g}$. The doses administered were $0.05,0.1,0.2,0.4,0.6$ and $1.0 \mathrm{~g}$. of glycine/rat, $0.05,0.1,0.2,0.4$ and $0.7 \mathrm{~g}$. of methionine/rat and $0 \cdot 1,0 \cdot 3,0.5$ and $1.0 \mathrm{~g}$. of leucine/rat.

\section{RESULTS}

In the first $24 \mathrm{hr}$. after protein has been withdrawn from the diet of the rat, there is a sharp decrease in the RNA content of the liver. Previous experiments (Munro et al. 1953; Clark et al. 1957) have shown that incorporation of ${ }^{32} \mathrm{P}$ and of $\left[{ }^{14} \mathrm{C}\right]$ glycine into RNA is much reduced during this period; these changes were rapidly reversed by feeding with casein just before injection of the isotopes. In the present series of experiments, a nutritionally incomplete protein has been used for feeding under the same circumstances, to see whether deficiency of essential amino acids might lead to a different response in metabolism of RNA from that evoked by casein. Table 1 shows that, as observed in the earlier studies, inclusion of casein in the meal fed just before injection of isotope produced a large increase in uptake of ${ }^{32} \mathrm{P}$ by RNA (relative specific activity and total relative activity). However, the feeding with zein had an effect which was statistically indistinguishable from that of casein and, moreover, the addition of the missing amino acids tryptophan and lysine to the zein did not alter the magnitude of the response.

In view of this finding with zein, mixtures of amino acids were tested. Table 2 shows that a mixture made up of all the essential amino acids except tryptophan increased total relative activity by $47 \%$, and a mixture of non-essential amino acids raised it by $136 \%$ above the level obtained by feeding with the protein-free meal alone. The latter figure exceeds the effect of $2.2 \mathrm{~g}$. of casein on uptake of ${ }^{32} \mathrm{P}$ by RNA. When the individual nonessential amino acids were given singly in $1 \mathrm{~g}$. doses (Table 3), glycine was the only component of the mixture which caused measurable changes in metabolism of RNA. In a further experiment (not reported here) it was found that the uptake of ${ }^{32} \mathrm{P}$ was unaffected by aspartic acid and glutamic acid even in doses of $2.2 \mathrm{~g}$./rat. A dose-response curve was constructed for glycine over the range 0.05$1.0 \mathrm{~g}$./rat (Fig. 1). The metabolism of RNA was not significantly affected until $0.4 \mathrm{~g}$. of glycine had been added to the protein-free meal; this distinctive pattern appeared in each repetition of the experiment and indicates a threshold dose for stimulation by glycine.

The essential amino acids (including cystine and tyrosine) were then given singly in $1 \mathrm{~g}$. doses

Table 1. Liver ribonucleic acid metabolism after feeding with casein or zein

Animals received a final meal of carbohydrate and fat to which was added the substance tested; $40 \mu \mathrm{C}$ of ${ }^{22} \mathrm{P}$ was injected $1 \mathrm{hr}$. after the final meal and the animals were killed $18 \mathrm{hr}$. later. The mean results from four experiments are shown. All additions to the diet significantly increased total relative activity $(P<0 \cdot 01)$, but the increment after feeding with casein was not significantly greater than that after zein fed alone or supplemented with tryptophan and lysine. Total relative activity is explained in Experimental Methods.

\begin{tabular}{|c|c|c|c|c|}
\hline \multirow[b]{2}{*}{ Addition to final meal } & \multirow[b]{2}{*}{$\begin{array}{l}\text { RNA P/100 g. } \\
\text { body wt. } \\
\text { (mg.) }\end{array}$} & \multicolumn{3}{|c|}{ Uptake of ${ }^{32} \mathrm{P}$ by RNA P } \\
\hline & & $\begin{array}{l}\text { Relative } \\
\text { specific } \\
\text { activity } \\
(\%)\end{array}$ & $\begin{array}{l}\text { Total } \\
\text { relative } \\
\text { activity }\end{array}$ & $\begin{array}{l}\text { Change in } \\
\text { total relative } \\
\text { activity } \\
(\%)\end{array}$ \\
\hline $\begin{array}{l}\text { None } \\
\text { Casein }(2 \cdot 2 \mathrm{~g} .) \\
\text { Zein }(2 \cdot 2 \mathrm{~g} .) \\
\text { Zein }(2 \cdot 2 \mathrm{~g} .)+0 \cdot 05 \mathrm{~g} . \text { of } \\
\text { tryptophan }+0 \cdot 1 \mathrm{~g} . \text { of lysine }\end{array}$ & $\begin{array}{l}\mathbf{3} \cdot 13 \\
\mathbf{3} \cdot 12 \\
\mathbf{3} \cdot 35 \\
2 \cdot 94\end{array}$ & $\begin{array}{l}17 \cdot 4 \\
38 \cdot 1 \\
29 \cdot 9 \\
\mathbf{3 3 \cdot 3}\end{array}$ & $\begin{array}{l}0.54 \\
1.18 \\
1 \cdot 00 \\
1 \cdot 01\end{array}$ & $\begin{array}{r}-119 \\
+85 \\
+87\end{array}$ \\
\hline
\end{tabular}




\section{Table 2. Liver ribonucleic acid metabolism after administration of essential and non-essential amino acid mixtures}

Animals received a final meal of carbohydrate and fat to which was added the substance tested; $40 \mu \mathrm{C}$ of ${ }^{32} \mathrm{P}$ was injected $1 \mathrm{hr}$. after the final meal and the animals were killed $18 \mathrm{hr}$. later. The figures are the means of two experiments. The feeding with casein and with the non-essential amino acid mixture raised total relative activity significantly $(P<0 \cdot 05)$.

\begin{tabular}{|c|c|c|c|c|}
\hline \multirow[b]{2}{*}{ Addition to final meal } & \multirow[b]{2}{*}{$\begin{array}{l}\text { RNA P/100 g. } \\
\text { body wt. } \\
\text { (mg.) }\end{array}$} & \multicolumn{3}{|c|}{ Uptake of ${ }^{32} \mathbf{P}$ by RNA P } \\
\hline & & $\begin{array}{c}\text { Relative } \\
\text { specific } \\
\text { activity } \\
(\%)\end{array}$ & $\begin{array}{l}\text { Total } \\
\text { relative } \\
\text { activity }\end{array}$ & $\begin{array}{l}\text { Change in } \\
\text { total relative } \\
\text { activity } \\
(\%)\end{array}$ \\
\hline None & 2.98 & $19 \cdot 4$ & 0.58 & - \\
\hline Casein $(2 \cdot 2 \mathrm{~g})$. & $\mathbf{3} \cdot \mathbf{7 3}$ & $34 \cdot 1$ & $1 \cdot 27$ & +119 \\
\hline $\begin{array}{l}\text { Essential amino acid mixture } \\
(2.0 \mathrm{~g} \text {. })\end{array}$ & $3 \cdot 69$ & $23 \cdot 3$ & 0.85 & +47 \\
\hline $\begin{array}{l}\text { Non-essential amino acid } \\
\text { mixture }(2.9 \mathrm{~g} .)\end{array}$ & $4 \cdot 09$ & $\mathbf{3 3} \cdot \mathbf{5}$ & $1 \cdot 37$ & +136 \\
\hline
\end{tabular}

Table 3. Liver ribonucleic acid metabolism after administration of individual non-essential amino acids

Animals received a final meal of carbohydrate and fat to which was added the amino acid. The amino acids were used in $1 \mathrm{~g}$. quantities. $40 \mu \mathrm{C}$ of ${ }^{32} \mathrm{P}$ was injected $1 \mathrm{hr}$. after the final meal and the animals were killed $18 \mathrm{hr}$. later. The figures are the means of two experiments. There are no statistically significant differences in total relative activity except with glycine $(P<0.01)$.

\begin{tabular}{|c|c|c|c|c|}
\hline \multirow{2}{*}{$\begin{array}{l}\text { Addition to } \\
\text { final meal }\end{array}$} & \multirow[b]{2}{*}{$\begin{array}{l}\text { RNA P/100 g. } \\
\text { body wt. } \\
\text { (mg.) }\end{array}$} & \multicolumn{3}{|c|}{ Uptake of ${ }^{32} \mathrm{P}$ by RNA P } \\
\hline & & $\begin{array}{c}\text { Relative } \\
\text { specific } \\
\text { activity } \\
(\%)\end{array}$ & $\begin{array}{c}\text { Total } \\
\text { relative } \\
\text { activity }\end{array}$ & $\begin{array}{l}\text { Change in } \\
\text { total relative } \\
\text { activity } \\
(\%)\end{array}$ \\
\hline None & $3 \cdot 40$ & $22 \cdot 2$ & $0 \cdot 73$ & - \\
\hline L-Glutamic acid & $3 \cdot 16$ & $24 \cdot 3$ & 0.77 & +6 \\
\hline L-Aspartic acid & $3 \cdot 26$ & $25 \cdot 6$ & $0 \cdot 84$ & +16 \\
\hline DL-Serine & $3 \cdot 39$ & $24 \cdot 6$ & 0.84 & +16 \\
\hline DL-Alanine & $3 \cdot 56$ & $22 \cdot 3$ & 0.79 & +9 \\
\hline L-Proline & $2 \cdot 78$ & $24 \cdot 2$ & 0.68 & -6 \\
\hline Glycine & $\mathbf{3 \cdot 8 7}$ & $34 \cdot 2$ & $1 \cdot 30$ & +80 \\
\hline
\end{tabular}

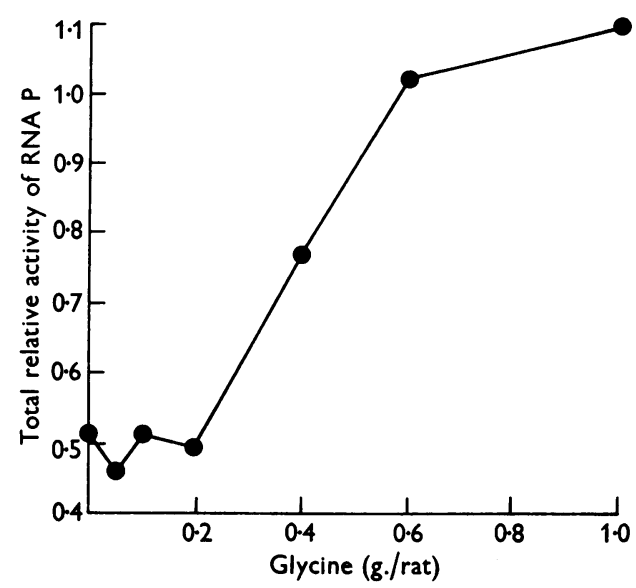

Fig. 1. Uptake of ${ }^{32} \mathrm{P}$ by liver ribonucleic acid (total relative activity) after administration of different doses of glycine to rats of uniform size. The rats received a meal of carbohydrate and fat to which the glycine was added. $40 \mu \mathrm{C}$ of ${ }^{32} \mathrm{P}$ was injected $1 \mathrm{hr}$. after the meal and the animals were killed $18 \mathrm{hr}$. later. Each point is the mean from two experiments. The action of glycine on total relative activity is highly significant $(P<0.01)$.
(Table 4). In this instance, there was a less clearcut distinction between amino acids affecting RNA metabolism and those not affecting it. Statistically significant differences between treatments which would correspond to 1 and $5 \%$ probability levels were established by analysis of variance of the results as a whole. After two amino acids, Imethionine and DL-leucine, total relative activity was greater than that of the control group by a difference which exceeded the $1 \%$ probability level. Feeding with L-cystine and with L-tryptophan caused increments reaching the $5 \%$ probability level, but with cystine this effect was due to one exceptionally large figure, and with tryptophan the response just attained the $5 \%$ probability level. It was considered that only with methionine and leucine were the effects on RNA metabolism sufficient to justify further exploration. Doseresponse curves for L-methionine and L-leucine were therefore constructed (Figs. 2, 3). In contrast with glycine (Fig. 1), both amino acids produced a response in metabolism of RNA which was approximately linear over the dose range studied. All rats receiving more than $0.2 \mathrm{~g}$. of methionine 
Table 4. Liver ribonucleic acid metabolism after administration of individual essential amino acids

Animals received a final meal of carbohydrate and fat to which was added the amino acid. The amino acids were used in $1 \mathrm{~g}$. quantities. $40 \mu \mathrm{C}$ of ${ }^{32} \mathrm{P}$ was injected $1 \mathrm{hr}$. after the final meal and the animals were killed $18 \mathrm{hr}$. later. For convenience of handling, the amino acids were divided into two arbitrary groups. Figures are the means of three experiments. Statistical analysis shows a highly significant difference between animals fed with methionine or leucine and the control group $(P<0 \cdot 01)$. With cystine and tryptophan, the increment is just significant $(P<0 \cdot 05)$.

\begin{tabular}{|c|c|c|c|c|}
\hline \multirow[b]{2}{*}{$\begin{array}{l}\text { Addition to } \\
\text { final meal }\end{array}$} & \multirow[b]{2}{*}{$\begin{array}{l}\text { RNA P/100 g. } \\
\text { body wt. } \\
\text { (mg.) }\end{array}$} & \multicolumn{3}{|c|}{ Uptake of ${ }^{32} \mathrm{P}$ by RNA P } \\
\hline & & $\begin{array}{c}\text { Relative } \\
\text { specific } \\
\text { activity } \\
(\%)\end{array}$ & $\begin{array}{c}\text { Total } \\
\text { relative } \\
\text { activity }\end{array}$ & $\begin{array}{l}\text { Change in } \\
\text { total relative } \\
\text { activity } \\
(\%)\end{array}$ \\
\hline None & $3 \cdot 47$ & $21 \cdot 2$ & 0.75 & - \\
\hline DL-Threonine & $3 \cdot 02$ & $18 \cdot 9$ & 0.58 & -23 \\
\hline L-Lysine & $3 \cdot 29$ & $24 \cdot 5$ & $0 \cdot 80$ & +7 \\
\hline L-Histidine & $3 \cdot 38$ & $26 \cdot 8$ & 0.92 & +23 \\
\hline L-Phenylalanine & $3 \cdot 43$ & $28 \cdot 4$ & 0.97 & +30 \\
\hline L-Valine & $4 \cdot 04$ & $25 \cdot 6$ & $1 \cdot 02$ & +36 \\
\hline None & $\mathbf{3} \cdot 24$ & $19 \cdot 4$ & $0 \cdot 62$ & - \\
\hline DL-Isoleucine & $2 \cdot 94$ & $18 \cdot 6$ & 0.56 & -10 \\
\hline L-Arginine & $3 \cdot 11$ & $24 \cdot 0$ & $0 \cdot 74$ & +19 \\
\hline L-Tyrosine & $3 \cdot 51$ & $22 \cdot 3$ & $0 \cdot 79$ & +27 \\
\hline L-Tryptophan & $3 \cdot 43$ & $26 \cdot 6$ & 0.91 & +47 \\
\hline L-Cystine & $3 \cdot 87$ & $25 \cdot 8$ & 0.97 & +56 \\
\hline DL-Leucine & $4 \cdot 11$ & $25 \cdot 4$ & 1.04 & +68 \\
\hline L-Methionine & $3 \cdot 63$ & $\mathbf{3 3} \cdot \mathbf{3}$ & $1 \cdot 21$ & +95 \\
\hline
\end{tabular}

in the final meal showed considerable gastric retention when killed $18 \mathrm{hr}$. later.

From these experiments it is apparent that glycine, methionine and leucine each have a considerable effect on uptake of ${ }^{32} \mathrm{P}$ by liver RNA. Tables 3 and 4 show that, associated with this action, there is a small increment in the amount of RNA in the liver. To evaluate this change statistically, all available experiments involving these three amino acids have been collected into Table 5. In each instance, the animals receiving the amino acid have more RNA/liver than similar control animals.

The final experiment deals with the application of these findings to the action of zein on metabolism of RNA. According to published analyses (Block \& Bolling, 1951) zein contains $23.7 \%$ of leucine, $2.3 \%$ of methionine and no glycine. In order to determine whether the high leucine content of zein might account for its stimulant action on metabolism of RNA, rats were fed with a mixture of amino acids in the same proportions as they occur in zein. A control group received the same mixture with all the leucine replaced by an equimolar quantity of alanine. Table 6 shows that the mixture containing leucine increased uptake of ${ }^{32} \mathrm{P}$ by $77 \%$, which is comparable with the action of zein (Table 1). However, the corresponding mixture without leucine produced a $36 \%$ increment above the basal level, which indicates that the other amino acids made some contribution to the response. This is not likely to be due to the small amount of methionine in the mixture, since reference to the dose-response curve for methionine

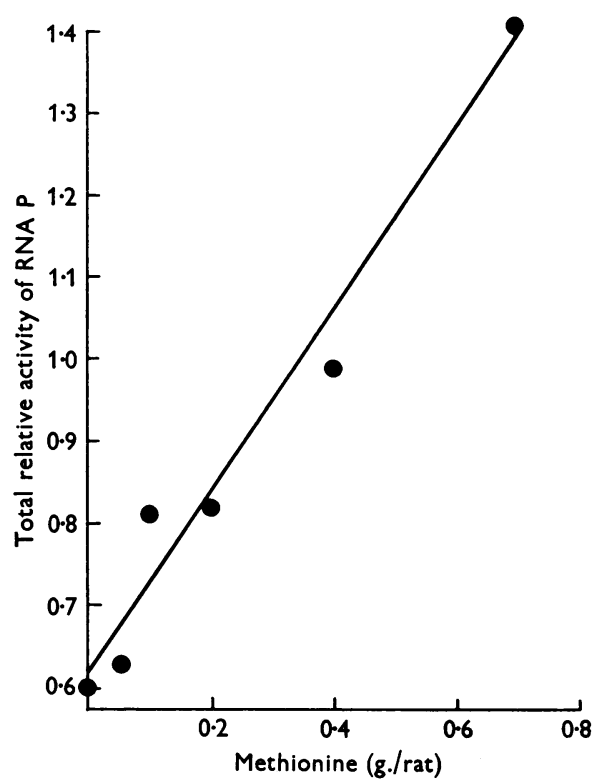

Fig. 2. Uptake of ${ }^{32} \mathrm{P}$ by liver ribonucleic acid (total relative activity) after administration of different doses of L-methionine to rats of uniform size. The rats received a meal of carbohydrate and fat to which the methionine was added. $40 \mu \mathrm{C}$ of ${ }^{32} \mathrm{P}$ was injected $1 \mathrm{hr}$. after the meal and the animals were killed $18 \mathrm{hr}$. later. Each point is the mean from two experiments. The data are described by the equation $Y=0.62+1.09 X$, where $X$ is the dose of methionine, in g./rat, and $Y$ represents total relative activity. The regression coefficient is highly significant $(P<0.01)$. 
(Fig. 2) shows that a dose of $44 \mathrm{mg}$./rat would not produce a measurable increase in total relative activity.

In the same experiment, the protein content of the liver was also examined (Table 6). The stimulus to metabolism of RNA is accompanied by a greater amount of protein in the liver, but the effect fails to attain statistical significance. However, significant changes were observed in the experiment in which the response of metabolism of RNA to increasing doses of L-leucine was explored (Fig. 3). At dose levels of $0,0.1,0.3,0.5$ and $1.0 \mathrm{~g}$. of leucine, the average protein content of the livers was $64,65,68,70$ and $72 \mathrm{mg}$. of $\mathrm{N} / 100 \mathrm{~g}$. of body wt. respectively. The correlation coefficient for these data is +0.60 , which is significant $(P=0.05$ $0.02)$.

\section{DISCUSSION}

In an earlier study (Clark et al. 1957), it was concluded that the metabolism of ribonucleic acid in the liver is influenced by the dietary supply of amino acids available for synthesis of protein. The present investigation was begun in order to test the response of the metabolism to the feeding of proteins deficient in one or more essential amino

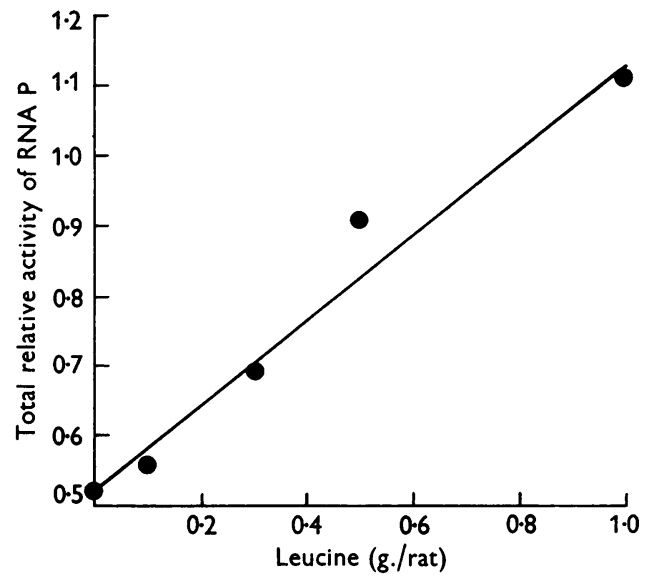

Fig. 3. Uptake of ${ }^{32} \mathrm{P}$ by liver ribonucleic acid (total relative activity) after administration of different doses of L-leucine to rats of uniform size. The rats received a meal of carbohydrate and fat to which the leucine was added. $40 \mu \mathrm{C}$ of ${ }^{32} \mathrm{P}$ was injected $1 \mathrm{hr}$. after the meal and the animals were killed $18 \mathrm{hr}$. later. Each point is the mean from three experiments. The data are described by the equation $Y=0.52+0.62 X$, where $X$ is the dose of leucine, in $\mathrm{g} . / \mathrm{rat}$, and $Y$ represents total relative activity. The regression coefficient is highly significant $(P<0.01)$.

Table 5. Changes in the amount of liver ribonucleic acid after administration of individual amino acids

Animals received a final meal of carbohydrate and fat to which $1 \mathrm{~g}$. of the amino acid was added. Control rats were given the protein-free meal alone. All rats were killed $19 \mathrm{hr}$. later. Statistical analysis shows that each amino acid in. creased the amount of RNA/liver significantly $(P<0.01$ for glycine, $P<0.05$ for methionine and for the combined results for leucine).

\begin{tabular}{|c|c|c|c|c|}
\hline \multirow[b]{2}{*}{$\begin{array}{l}\text { Substance } \\
\text { administered }\end{array}$} & \multirow[b]{2}{*}{$\begin{array}{l}\text { No. of } \\
\text { comparisons }\end{array}$} & \multicolumn{3}{|c|}{ RNA P/100 g. body wt. } \\
\hline & & $\begin{array}{l}\text { Control } \\
\text { series } \\
\text { (mg.) }\end{array}$ & $\begin{array}{l}\text { Animal fed } \\
\text { with amino acid } \\
\text { (mg.) }\end{array}$ & $\begin{array}{c}\text { Change } \\
(\%)\end{array}$ \\
\hline $\begin{array}{l}\text { Glycine } \\
\text { L-Methionine } \\
\text { L-Leucine } \\
\text { DL-Leucine }\end{array}$ & $\begin{array}{l}5 \\
6 \\
8 \\
7\end{array}$ & $\begin{array}{l}\mathbf{3} \cdot 34 \\
\mathbf{3} \cdot 13 \\
2 \cdot 79 \\
\mathbf{3} \cdot 11\end{array}$ & $\left.\begin{array}{l}\mathbf{3} \cdot 84 \\
\mathbf{3} \cdot 56 \\
\mathbf{2} \cdot 98 \\
\mathbf{3} \cdot 49\end{array}\right\}$ & $\begin{array}{r}+15 \\
+14 \\
+9\end{array}$ \\
\hline
\end{tabular}

Table 6. Liver ribonucleic acid metabolism after administration of an amino acid mixture resembling zein in composition

Animals received a final meal of carbohydrate and fat to which was added the amino acid mixture. A control group received the mixture with all the leucine replaced by alanine. $40 \mu \mathrm{C}$ of ${ }^{32} \mathrm{P}$ was injected $1 \mathrm{hr}$. after the final meal and the animals were killed $18 \mathrm{hr}$. later. The figures are the means of five experiments. Both amino acid mixtures increased total relative activity significantly $(P<0.01$ for the mixture containing leucine; $P=0.02-0.01$ for the mixture without leucine).

\begin{tabular}{|c|c|c|c|c|c|}
\hline \multirow[b]{2}{*}{ Addition to final meal } & \multirow[b]{2}{*}{$\begin{array}{l}\text { RNA P/100 g. } \\
\text { body wt. } \\
\text { (mg.) }\end{array}$} & \multicolumn{3}{|c|}{ Uptake of ${ }^{32} \mathrm{P}$ by RNA P } & \multirow[b]{2}{*}{$\begin{array}{l}\text { Liver protein } \\
\mathrm{N} / 100 \mathrm{~g} . \\
\text { body wt. } \\
\text { (mg.) }\end{array}$} \\
\hline & & $\begin{array}{c}\text { Relative } \\
\text { specific } \\
\text { activity } \\
(\%)\end{array}$ & $\begin{array}{l}\text { Total } \\
\text { relative } \\
\text { activity }\end{array}$ & $\begin{array}{l}\text { Change in } \\
\text { total relative } \\
\text { activity } \\
(\%)\end{array}$ & \\
\hline $\begin{array}{l}\text { mixture }(2.2 \mathrm{~g} .) \\
\text { mixture less leucine }(2.0 \mathrm{~g} .)\end{array}$ & $\begin{array}{l}2 \cdot 86 \\
3 \cdot 23 \\
2 \cdot 91\end{array}$ & $\begin{array}{l}15 \cdot 3 \\
23 \cdot 8 \\
21 \cdot 0\end{array}$ & $\begin{array}{l}0.42 \\
0.74 \\
0.57\end{array}$ & $\begin{array}{r}- \\
+77 \\
+36\end{array}$ & $\begin{array}{l}69 \\
78 \\
74\end{array}$ \\
\hline
\end{tabular}

None

Amino acid mixture $(2 \cdot 2 \mathrm{~g}$.

Amino acid mixture less leucine $(2 \cdot 0 \mathrm{~g}$.

$2 \cdot 91$ 
acids. It is apparent from our findings with zein that factors other than the biological value of a protein can determine its effect on metabolism of ribonucleic acid in the liver. Certain individual amino acids, notably glycine, methionine and leucine, stimulate uptake of ${ }^{32} \mathrm{P}$ considerably, and the action of zein is largely attributable to its high leucine content (Table 6).

The significance of this action of individual amino acids on metabolism of ribonucleic acid has still to be explored. We can exclude the possibility that the observed changes are artifacts of isotope incorporation arising from distortion of the product-precursor relationship; after feeding with glycine, methionine or leucine there was a signifcant increase in the total amount of ribonucleic acid in the liver (Table 5). The changes in metabolism of ribonucleic acid which follow feeding with these three amino acids are probably secondary to alterations in the rate of liver-protein synthesis. In leucine-fed rats there is an accumulation of protein in the liver in parallel with the changes in uptake of ${ }^{32} \mathrm{P}$ (Fig. 3), and on the basis of our earlier investigations (Clark et al. 1957) we can interpret this to mean that leucine produces an increase in the rate of protein synthesis leading to greater incorporation of isotope into ribonucleic acid. Although the liver protein of glycine-fed and methionine-fed rats was not measured, it is probable that the action of these two amino acids on metabolism of ribonucleic acid can be similarly explained. Even if we accept this explanation, the mechanism underlying the increase in the protein content of the liver remains obscure. It may depend on an increased secretion of hormones from the adrenal cortex. There is evidence that perfusion of the eviscerated dog with solutions of certain amino acids leads to an increase in the secretory activity of the cortex (Vogt, 1951), and it has been conclusively established that one action of cortisone is to cause protein to accumulate in the liver (see review by Trémolières, Derache \& Lowy, 1955).

The nutritional significance of our findings has still to be evaluated. The addition of excessive amounts of individual amino acids to diets gives rise to amino acid imbalances and toxicities (see review by Harper, 1956), and our observations are presumably related to such effects. When zein is the sole protein of the diet, the action of leucine does not result in any permanent rise in the amount of protein in the liver. Campbell \& Kosterlitz (1948) studied the non-glycogen nonlipid solids of liver (essentially a measure of liverprotein content) during the first 3 days of feeding with a diet containing, as protein source, zein supplemented with lysine. On the first day the level of liver solids was much higher than on the first day of a protein-free diet, but by the third day the group fed on zein had lost this advantage. This suggests that the action of zein on the protein content of the liver may occur only before protein depletion has set in.

\section{SUMMARY}

1. The uptake of ${ }^{32} \mathrm{P}$ by liver ribonucleic acid has been studied after administration of certain proteins, amino acid mixtures and individual amino acids.

2. Feeding with the nutritionally incomplete protein zein resulted in the same increase in ${ }^{32} \mathbf{P}$ uptake as did the feeding with casein. Addition of tryptophan and lysine to zein did not alter the magnitude of the response.

3. Eighteen amino acids were used for feeding singly in large doses and it was established that glycine, methionine and leucine each caused a significant increment in uptake of ${ }^{32} \mathrm{P}$. The responses after the feeding of methionine and of leucine were proportional to the dose administered, whereas the response to glycine occurred only after a threshold dose had been reached.

4. Experiments with a mixture of amino acids in the proportions found in zein confirmed that its high leucine content can account for a large part of its action on metabolism of ribonucleic acid.

5. The protein content of the liver is increased by administration of leucine, and it is concluded that the changes in metabolism of ribonucleic acid after the feeding of glycine, methionine and leucine are secondary to an increased rate of synthesis of liver protein.

We acknowledge gratefully a grant for part-time scientific assistance from the Medical Research Council to one of us (H.N.M.) which made this work possible. Skilled technical assistance was given by $\mathrm{Mr}$ S. Caine.

\section{REFERENCES}

Block, R. J. \& Bolling, D. (1951). The Amino Acid Composition of Proteins and Foods, 2nd ed. Springfield, Ill.: Thomas Publisher.

Campbell, I. G., Olley, J. \& Blewett, M. (1949). Biochem. J. $45,105$.

Campbell, R. M. \& Kosterlitz, H. W. (1948). J. Physiol. 107, 383.

Clark, C. M., Naismith, D. J. \& Munro, H. N. (1957). Biochim. biophys. Acta, 23, 587.

Harper, A. E. (1956). Nutr. Rev. 14, 225.

Munro, H. N. \& Naismith, D. J. (1953). Biochem.J. 54, 191.

Munro, H. N., Naismith, D. J. \& Wikramanayake, T. W. (1953). Biochem. J. 54, 198.

Rose, W. C., Oesterling, M. J. \& Womack, M. (1948). J. biol. Chem. 176, 755.

Trémolières, J., Derache, R. \& Lowy, R. (1955). Ann. Nutr., Paris, 9, 179.

Vogt, M. (1951). J. Physiol. 113, 129.

Young, L., Edson, M. \& McCarter, J. A. (1949). Biochem. J. 44, 179. 